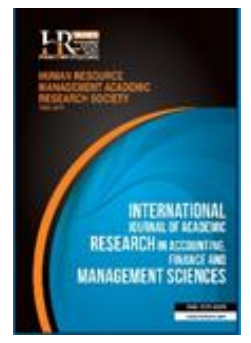

International Journal of Academic Research in Accounting, Finance and Management Sciences

Vol. 8, No.3, July 2018, pp. 310-324

E-ISSN: 2225-8329, P-ISSN: 2308-0337

(c) 2018 HRMARS

www.hrmars.com

To cite this article: Oboh, J.O., Chinonyelum, O.J., Edeme, R.K. (2018). Tax Revenue and Economic Growth in Selected ECOWAS Countries, Evidence from Sure Model, International Journal of Academic Research in Accounting, Finance and Management Sciences 8 (3): 310-324.

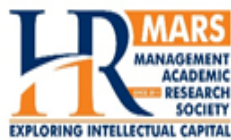

http://dx.doi.org/10.6007/IJARAFMS/v8-i3/4917 (DOI: 10.6007/IJARAFMS/v8-i3/4917)

\title{
Tax Revenue and Economic Growth in Selected ECOWAS Countries, Evidence from Sure Model
}

\section{Joshua Ose $\mathrm{OBOH}^{1}$, Okafor Joan CHINONYELUM ${ }^{2}$, Richardson Kojo EDEME ${ }^{3}$}

\author{
1,3 Department of Economics, University of Nigeria, Nsukka, Nigeria, ${ }^{1}$ E-mail: joshuaoseoboh@gmail.com, \\ ${ }^{3}$ E-mail(s): richard.edeme@unn.edu.ng; kojodynamics@yahoo.com (Corresponding author) \\ ${ }^{2}$ Department of Business Administration \& Management Technology, Abia State Polytechnic Aba-Nigeria,
} 2E-mail:nonyjoan@yahoo.com

\begin{abstract}
The need for African countries to improve tax revenue-GDP ratio has open up debate among policy makers. This study is motivated to analyse the impact of tax revenue, direct and indirect tax on economic growth of ECOWAS countries, using Seemingly Unrelated Regression Estimate (SURE) analysis for five selected Economic Community of West African States (Nigeria, Ghana, Sierra Leone, Benin and Burkina Faso) using data from 2000-2015 generated from World Bank World Development Indicators, 2016. Findings reveal that total tax revenue has positive and significant effect on economic growth an increase in total tax revenue by \$1 causes economic growth by 43.2 percent while an increase in direct tax revenue by the same amount dampens growth by -3.08 percent, an indication that direct tax is unproductive in the countries of study. Also an increase in indirect tax revenue by \$1 led to a corresponding increase in economic growth by 47.7 percent. For those countries where indirect tax are unproductive, there is need to broaden indirect tax base instead of direct tax rate.

Key words Tax Revenue; Direct Tax, Indirect Tax, Economic Growth; ECOWAS; Seemingly Unrelated Regression Estimate Analysis

Received: 18 Oct $2018 \quad$ C The Authors 2018

Revised: 30 Oct 2018 Published by Human Resource Management Academic Research Society (www.hrmars.com)

Accepted: 20 Nov 2018 This article is published under the Creative Commons Attribution (CC BY 4.0) license. Anyone may reproduce, distribute, translate and create derivative works of this article (for both commercial and noncommercial purposes), subject to full attribution to the original publication and authors. The full terms of this license may be seen at: http://creativecommons.org/licences/by/4.0/legalcode
\end{abstract}

\section{Introduction}

The relationship between tax revenue and economic growth has open up debate among policy makers over the years and studies have shown that the allocation of tax resources in an economy is affected by fiscal policies which often generate behavioural distortions of economic agents. Scrutinizing the effects of tax policy on economic growth shows the existence of both exogenous and endogenous school of thoughts. The exogenous school focused on the exogenous growth model as pioneered by Solow (1956) postulates that tax policy has a role to play in attaining long-term economic growth, on the premise that labour and technological progress (which is key factors responsible for economic expansion) are determined outside the model. At the other extreme is the endogenous school of thought that focused on the endogenous growth models which according to Lucas (1988), King and Rebelo (1990) and Barro (1990) postulates that tax policy have a relationship with economic growth and welfare over time, and economic expansion is determined within the model. In an assessment of growth performance of developing countries, the International Monetary Fund (IMF) (2005) recommends ratio of 15-20 percent of tax revenue-GDP relationship as a reasonable minimum threshold for developing countries. This to further 
support the assertion of Martin and Lewis (1956) who intended a revenue-to-GDP ratio of 17-19 percent and Kaldor (1963) who argued that a country's revenue-GDP ratio needed to be closer to 25-30 percent in order to experience reasonable growth. Obara and Nangih (2017) content that lack of reliable tax database and prevalence of cash transactions among Small and Medium Enterprises impedes government revenue generation in Nigeria. Since 1987, various tax modifications have been undertaken by many developing economies, the Economic Community of West African States (ECOWAS) such as adoption of the ECOWAS Monetary Cooperation Programme (EMCP) criterion on tax revenue performance to encourage member countries to improve tax revenue to at least $20 \%$ of GDP. Unfortunately, ECOWAS countries have failed to meet this threshold, despite the fact that such expansion is not only necessary but also achievable using broad-based revenue source and strengthening tax collection (UN Millennium Project 2005). Available data from World Development Index (2015) reveals that tax revenue-GDP ratio for Nigeria, Ghana, Sierra Leone, Benin Republic and Burkina Faso between 2000 and 2015 is $8.78 \%, 16.86 \%, 9.34 \%, 16.26 \%$ and $13.99 \%$ respectively. Except for Ghana in 2004 and 2005, none of the countries have been able to meet the secondary convergence criteria of the ECOWAS Monetary Cooperation Programme (EMCP) on Tax Revenue Performance. Ghana's tax revenue as a percentage of GDP grew between 2000 and 2005, that of Sierra Leone dwindled from $10.16 \%$ to $8.20 \%$ and that of Nigeria was fluctuating. Between 2012 and 2015, tax revenue-GDP ratio in Nigeria declined from $6.90 \%$ to $3.93 \%$, Sierra Leone from $9.51 \%$ to $9.09 \%$, Benin Republic from $14.41 \%$ to $13.70 \%$, Burkina Faso from $15.63 \%$ to $15.29 \%$ while that of Ghana increased from $14.64 \%$ to $16.84 \%$ (World Development Indicator, 2016). Looking at the growth for the same period, only Sierra Leone in 2001 and 2015 experienced negative growth and highest growth in 2002 and 2004 respectively. In 2001, economic growth rate was $1.8 \%$ with tax revenue-GDP ratio of $11.9 \%$. In 2004 , economic growth increased to $30.3 \%$ while tax revenue-GDP ratio was $10.2 \%$. What has become of concern of this study is the relationship between tax revenue and economic growth, the direction of relationship between tax revenue and economic growth if any exist and what type of tax type contributes most to economic growth.

\section{Theoretical and Empirical Literature Review}

In order to drive growth in the economy, the state provide certain goods and services to the members of the society and the society in return contributes to offset the cost of these supplies in proportion to the benefits they received. It has been argued that tax should be levied according to an individual's income or ability to pay. This is done on the basis of progressive tax; the tax rate increases as the taxable income increases (Jones and Rhoades, 2011). This is indeed the most equitable tax system this is because people with greater income or wealth who can afford to pay more taxes are taxed at a higher rate and vice versa, the theory is most equitable tax system also because it has been widely used in industrialized economics. The ability-to-pay approach does not treat government revenue and expenditures jointly and there is no relationship between government expenditure and tax revenue collected. The Equal sacrifice theory also holds that income, wealth and transaction should be taxed at a fixed percentage. This means that people who earn more should pay more taxes, but will not pay a higher rate of taxes. Musgrave \& Musgrave, (1989) contend that that if taxes are levied in proportion to the incomes of the individuals, it will extract equal sacrifice. Thus, equal sacrifice can be measured using the following scenarios: (i) each taxpayer forgoes the same absolute degree of utility obtained from income, (ii) each taxpayer sacrifices the same proportion of utility obtained from income, or (iii) each gives up the same utility for the last unit of income. The modern economists, however, differ with this view when they opined that when income increases, the marginal utility of income decreases and the equality of sacrifice can only be achieved if individual with high incomes are taxed at higher rates and those with low income are taxed at lower rates.

Empirical studies on tax-revenue and economic growth relationship has arrived at different outcomes. While a fraction agrees that an inverse relationship exist between tax revenue and economic growth, others found direct relationship to exist between tax revenue and economic growth. There are also others that contend that tax revenue has both positive and negative relationship with economic growth. The conflicting nature of these findings may be attributable to (i) different definitions of state in different countries and periods (i.e. whether it is central government, general government or local government), (ii) problems in measuring tax variables (Easterly and Rebelo, 1993, Engen and Skinner, 1996), (iii) difficulties in 
sorting out the impact of individual tax component on growth, because of the complex interactions of fiscal variables, (iv) difficulties in separating the impact on growth of other economic variables from the impact of fiscal variables only, and (v) lack of empirical data enabling acceptance or rejection of some theoretical thesis (lyke and Takumah 2015). Studies that found an inverse relationship between taxation and economic growth include Ferede and Dahlby (2012), Brian et al. (2012), Dackehag and Hansson (2012), Greenidge and Drakes (2009), Arnold (2008), Poulson and Kaplan (2008), Bania et al. (2007), Gwartney and Lawson (2006), Tosun and Abizadeh (2005), Tomljanovich (2004), Holcombe and Lacombe (2004) Padovano and Galli (2001), Ma (2001), Engen and Jonathan (1996), Easterly and Rebelo (1993), Plosser (1992) and Koester and Kormendi (1989). These studies can be likened to the supply-side economist who believed that high marginal tax rate reduces the level of economic activity and the rate of economic growth, thus supporting strongly the notion to decrease the marginal tax rate. Even though tax is good for the growth of the economy, the short-term reduction in economic growth reduces the size of the economy permanently. In support of this, Tomljanovich (2004) opine that higher taxes reduce short-term growth rates but do not affect growth rate in the long-term. The decomposition of total tax burden reveals that income tax, property tax and sales taxes have no significant effects on economic growth, while corporate taxes has significant effects on growth. Comparing the growth in 48 neighbouring countries, and controlling for the average state tax rate, the highest state marginal income tax rate and other factors, Holcombe and Lacombe (2004) reports that states that raised their income tax rates more than their neighbours had slower income growth. The results shows that increase of 13.25 percent in marginal tax rate reduce per capita income by about $\$ 377$ after thirty 30 years. Interpolating the result linearly, an increase raising tax rate would ultimately reduce the growth rate by 0.01 percent annually. Goff, Lebedinsky and Lile (2012) match adjacent pairs of states based either on location or, for states in the middle two quartiles of the respective distributions, based on population or land size ratio, scrutinize the effects of tax revenues on per capita Gross State Product (GSP) growth to show that higher tax burden reduces cumulative nominal GSP per capita growth by about 2 percent. When income tax and corporate tax revenues were employed as separate variables, it was discovered that the relationship between corporate taxes and economic growth is not statistically significant and that the marginal impact of higher individual income tax burdens is only about 20 percent of the impact of overall revenues.

Greenidge and Drakes (2009) utilized an unrestricted error correction model to examine tax policy and its effect on macroeconomic activity in Barbados. The approach, proposed by Pesaran and Shin (1997) jointly captured both short and long-run effects from a general autoregressive distributed-lag model. Tax indicators were constructed using a tax index and principal component analysis, and the result reveals that total and indirect taxation has contractionary effect on the economy in the short-run with no long-run impact, while direct taxation had negative impact on growth in both in the short-run and long run. Koester and Kormendi (1989) constructed measures on average and marginal income tax rates by regressing tax revenue on GDP and computed the measures in a growth regression model. They detected that tax rates seem to have negative impact on economic growth, with marginal tax rate having negative effect on the level of activity. Plosser (1992) compared the growth rate of per capita GDP of twenty four Organizations for Economic Co-operation and Development (OECD) countries between 1960 and1989 and calculated the correlation between taxation and economic growth as -0.52 . Easterly and Rebelo (1993) extended the analysis by using marginal rate of tax on different measures in regressions model which involves other determinants of expansion such as initial income, school enrolments, assassinations, revolutions and war casualties and concluded that that tax matters for economic growth is disturbingly fragile, as the two variables are an inversely correlated. Based on extended neoclassical growth model of Mankiw et al. (1992), Macek (2014) evaluated the impact of individual types of taxes on the economic growth of 21 OECD countries utilizing regression analysis for the period, 2000-2011. It was found that corporate taxation followed by personal income taxes and social security contributions are the most harmful to growth. Tosun and Abizadeh (2005) documented a decline in shares of payroll, goods and services and positive growth from personal and property taxes. A study on economic growth and tax charges in OECD countries reveals that economic growth has significant effect on tax mix of GDP per capita.

Engen and Jonathan (1996) re-examined the relationship between economic growth and taxation in the light of the accumulated economic evidence in the United States and other countries and reached a 
conclusion that there is no enough evidence to significantly say that high taxes are bad for economic growth, theoretically and empirically. The evidence is however align with lower taxes having modest positive effects on economic growth. Padovano and Galli (2001) also constructed similar tax measure and included a dummy to allow for modification in tax rates over time. It was found that the relationship between tax and the growth of the economy is statistically significant, which confirms that marginal tax rates and economic growth has negative relationship. Gwartney and Lawson (2006) indicated that high marginal tax rates, particularly rates of 50 percent or more, exert adverse impact on long-term growth. It was estimated that a reduction in a country's top marginal tax rate by 10 percent increases long-term annual growth by approximately 0.3 percent. Bania et al. (2007) after a study came to the conclusion that the relationship between economic growth and taxes should be quadratic and depend on spending. They uncover a positive linear effect and a negative quadratic effect of tax revenue on growth, with the growth effect hitting zero when revenues reach about 29 percent of personal income.

To determine whether tax structures affect aggregate economic growth, Arnold (2008) submerged various indicators of tax structure into a set of panel growth regressions model for 21 OECD countries, based on data from 1971-2004. The results suggest that income taxes are generally associated with lower economic growth than taxes on consumption and property. The findings allow the establishment of a ranking of tax instruments with respect to their relationship to economic growth. Property taxes and particularly recurrent taxes on immovable property, seem to be the most growth-friendly, followed by consumption taxes and then by personal income taxes. Corporate income taxes appear to have the most negative effect on growth. There is also evidence of a negative relationship between the progressivity of personal income taxes and growth. Poulson and Kaplan (2008) investigated the impact of state income taxes on economic growth in the United States and found that high marginal tax rate not only create disincentive to work and invest, it has overall effect of dampening growth. This suggests that although all taxes may have negative effect on economic growth, income tax have the greatest impact. In support of this, Ferede and Dahlby (2012) also found that higher corporate income tax rate lowers private investment and slow down economic growth.

Onakoya et al. (2016) investigated the impact of taxation on economic growth in Africa from 20042013. Using the Generalized Least Squares (GLS), findings indicated that tax revenue is positively related to growth, implying that taxation promotes economic growth. The study concluded that tax African countries need to improve tax revenue towards accelerating economic growth.

Other studies such as Lee and Gordon (2004) carried a research on tax structure and economic growth with data set from 70 countries during 1970-1997 and discovered that corporate tax rate is negatively correlated with economic growth. The estimate indicates that cutting corporate tax rate by 10 percent increase annual growth rate by 1.1 percent. The fixed-effects estimates using a panel data set constructed for the same period shows that an increase in tax revenue increases economic growth by about 1.8 percent. They added that lower corporate tax rates leads to lower personal tax revenue, which is consistent with the economic postulation that a lower corporate tax rate encourages more entrepreneurial activity. Providing further evidence of the impact of tax changes on economic growth, Furceri and Karras, (2009) used panel data from 26 OECD countries from 1965-2007 to show that the effect of an increase in taxes on growth is negative and persistent. Specifically, an increase in total tax rate has long-run effect on growth, ranging from -0.5 percent to -1 percent, an implication that an increase in social security has larger negative effect on growth than increase in the income tax.

Arisoy and Unlukaplan (2010) test the effect of direct-indirect tax revenue composition on economic growth for the Turkish Economy for the period of 1968-2006. In accordance with the predictions of the endogenous growth models, their findings suggest that the real output is positively related to indirect tax revenue, but direct taxation seems to have no significant effect. A similar analysis belongs to Scarlett (2011), who explores the impact of taxation on economic growth in Jamaica, using a general autoregressive distributed-lag model and quarterly data from 1990 to 2010. The findings indicate that increasing revenue from indirect taxes is more conducive to economic growth in the long run; on the other hand, increasing the share of taxes from personal income has the greatest harm on per capita GDP over time. Xing (2011, 2012) conducted an empirical analysis based on the error correction model and reached the conclusion that reducing income taxes, consumption taxes, and increasing property taxes promote economic growth. 
Although there was no evidence that to foster economic growth, personal income taxes are better than corporate income taxes, and consumption taxes are better than income taxes. Okafor (2012) adopted the ordinary least square regression analysis technique to explore the relationship between Nigeria's economic growth and a set of federal government income revenue heads from 1981-2007. The result indicated a very positive and significant relationship between the components of tax revenue and the growth of the economy.

Yakovlev (2014) estimates the associative impact of average tax rate, personal income tax and its progressivity on several measures of growth. The estimated coefficients reveal that average tax rate is negatively and significantly related to growth. However both variables lost statistical significance, while average tax rate became negative and significant in the GMM model that treats all variables as endogenous. The analysis of multiple indicators reveals that higher state taxes are generally associated with lower economic performance, even after controlling for tax endogeneity. In a similar study, Ugwunta and Ugwuanyi (2015) used data from cross-section of countries from Sub-Saharan African to determine the effect of distortionary and non-distortionary taxes on economic growth. The relationship was linearly modelled with panel data estimation technique under the fixed-effect alternative. Findings reveal that distortionary tax had negative and insignificant effect while non-distortionary tax had positive and insignificant effect on economic growth.

\section{Methodology of Research}

Bearing in mind that apart taxation, other fiscal variables are considered in growth studies; the following variables were used as predictors of economic growth: total tax revenue, direct tax revenue, indirect tax revenue and other control variables such as openness, foreign direct investment and total population. Tax revenue was extracted as ratio of GDP while other was generated in nominal values. Data from 5 ECOWAS countries (Nigeria, Ghana, Sierra Leone, Benin Republic and Burkina Faso) from 2000-2015 were sourced variously from World Development Indicators (2016), African Development Indicators (2016), OECD. Stat, Quandl.com, West African Monetary Institute (2016), Federal Inland Revenue Service (FIRS) Nigeria and Ministry of Finance (MOF) Ghana. In the countries covered by the study, different currency is used. For Nigeria it is Naira, Ghana is GHC, Sierra Leone is (SLL) Le while Benin Republic and Burkina Faso use CFA. For appropriately of analysis, the tax revenue was converted to a single currency which is US Dollar (\$).

The theoretical underpinning for this study is the Romer and Barro (1990) growth model which advocates that the driver of economic growth is fundamentally the endogenous and exogenous factors. Romer (1986), Barro (1990) among others, points out channels by which policy variables cannot only affect the level of output, but also steady-state growth rates. Barro (1990) distinguishes four categories of public finances: productive vs. non-productive expenditures and distortionary versus non-distortionary taxation. Taxation is distortionary if it affects the investment decision, and hence, growth. This is the case for direct income and profit taxation. Otherwise taxes, such as consumption taxes, are considered non-distortionary, except for the case when households face the endogenous choice of labour or leisure. According to endogenous growth theory, fiscal policy can affect both the level of per capita output and the growth rate of per capita output. Barro (1990) and Barro and Sala $(1992,1995)$ employed a modified Cobb-Douglas production framework with government provided goods and services (g) as input to show the effect of productive government spending and the adverse effects associated with direct taxes. The production function, in per capita terms is of the form:

$$
Y=A k^{1-\alpha} g^{\alpha}
$$

$\mathrm{Y}$ is per capita output; $\mathrm{A}$ is the productivity factor, $\mathrm{k}$ is capital and $\mathrm{g}$ is government provided goods and services, $1-\alpha$ is the proportion of capital augmented by technological progress and $\alpha$ is the proportion of government provided goods and services. Arising from equation (3), the relationship between economic factors and growth can be expressed as:

$$
f=I(1-\mathrm{t})^{(1-\mathrm{a})} \mathrm{A}^{1 /(1-\mathrm{a})}(\mathrm{g} / \mathrm{y})^{\mathrm{a} /(1-\mathrm{a})}-\mathrm{m}
$$


Following from the theoretical and empirical literature, the relationship between tax variables and other control variables can be expressed as:

$$
r G D P=f(1-t)^{(1-a)} T T^{1 /(1-b)} O P N^{a /(1-c)} P O P^{1 /(1-d)} F D I^{a /(1-e)}
$$

rGDP is economic growth (proxied by real growth in GDP), TTR is Total tax revenue, OPN is economy openness, POP is population, FDI is foreign direct investment. Incorporating both direct and indirect tax and keeping all the explanatory variables, the log-linearized relations can be written separately as:

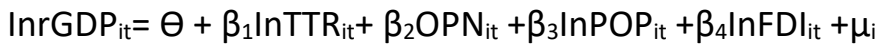

$$
\begin{aligned}
& \ln \operatorname{lDP}_{\mathrm{it}}=\beta+\Theta_{1} \operatorname{lnDTR}_{\mathrm{it}}+\Theta_{2} \mathrm{OPN}_{\mathrm{it}}+\Theta_{3} \ln \mathrm{nOP}_{\mathrm{it}}+\Theta_{4} \operatorname{lnFDI_{it}}+\mu_{\mathrm{it}} \\
& \ln r G D P_{i t}=\Omega+\alpha_{1}|n| T R_{i t}+\alpha_{2} O_{\text {Pit }}+\alpha_{3} \operatorname{lnPOP} P_{i t}+\alpha_{4} \operatorname{lnFDI}{ }_{i t}+\mu_{i}
\end{aligned}
$$

Where:

DTR $=$ direct tax revenue, ITR $=$ indirect tax revenue, $\theta, \theta \Omega=$ intercept, $U_{i t}=$ error terms which denotes other variables that are not specified in the model; i represent the number of countries and $t$ is the number of years. The parameter estimates $t>0$. The error term was decomposed as $\mu_{i}=\eta_{t}+\varepsilon_{i t}$. Here $\varepsilon_{\text {it }}$ is the standard disturbance term, which varies across years and countries, while $\eta_{t}$ is a set of group specific effects, which refer to each country in the model.

The above relationship can be written in SURE model as:

$$
Y_{i t}=\beta_{i 1} X_{i t 1} \beta_{i 2} X_{i t 2}+\ldots .+\beta_{i k i} X_{i t k i} \varepsilon_{i t} ; \mathrm{i}=1(1) \mathrm{N}, \mathrm{t}=1(1) \mathrm{T}
$$

The $b^{\prime}$ 's are allowed to vary across the country but they are constant over time and there is the possibility of each possessing different numbers of explanatory variables (individual $i$ has $k_{i}$ variables), however each state has same numbers of observations. For the ith state, the above relationship written more concise form using matrix notation as follows:

$Y_{i}=X_{i} B_{i}+\varepsilon_{i}$ for all $\mathrm{i}=1,2, \ldots \mathrm{n}$

Where:

The dimension of $Y_{i}$ is $T x 1$, the dimension of $X_{i}$ is $T x k_{i}$, the dimension of $\beta_{i}$ is $k_{i} x 1$ and the dimension of $\epsilon_{i}$ is $T x 1$. N. Stacking all the number of states, the matrix representation of the model is written as:

$$
\begin{aligned}
& Y_{i}=X_{i} B_{i}+\varepsilon_{i} \\
& Y_{2}=X_{2} B_{2}+\varepsilon_{2} \\
& \cdot \\
& \cdot \\
& Y_{n}=X_{n} B_{n}+\varepsilon_{n}
\end{aligned}
$$

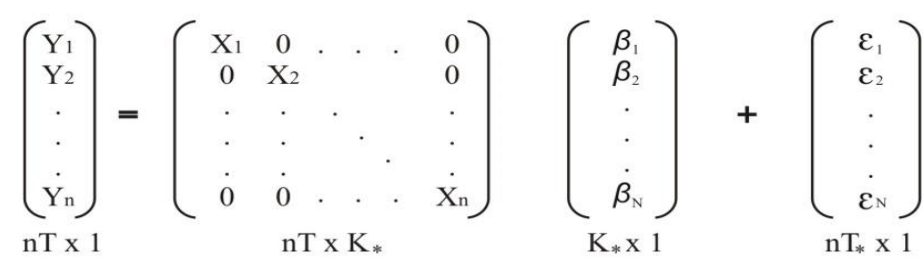

The error structure is displayed as:

$$
\begin{aligned}
& \sigma
\end{aligned}
$$

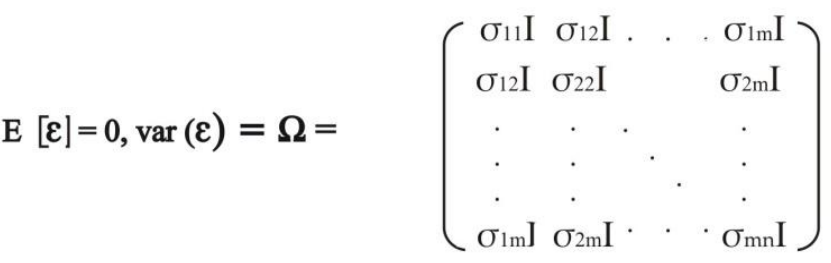


Although estimating $B i$ with ordinary least square (OLS) per equation is consistent, it is inefficient if the disturbances for the different individuals display contemporaneous correlation and the repressor sets differ from each specific equation. The efficiency gains of generalized least square (GLS) over OLS tend to be greater when the contemporaneous correlation in errors across equations $\left(\sigma_{i j}\right)$ is greater and there is less correlation between $X$ across equations. To obtain estimation of the parameters $\left(\beta_{i}\right)$ of the SURE model the Generalized least squares (GLS) method can be used because it is unbiased, efficient and meets the maximum likelihood requirement. This study focuses on five ECOWAS countries and to account for the heterogeneity and the jointness of the equations to be estimated based on different countries, the Seemingly Unrelated Regression (SURE) model proposed by Zellner (1962) and extended by Srivastava, Giles and David (1987) is adopted. The basic idea of the SURE model is that the jointness of various equations is explained by its structure and the covariance matrix of the associated disturbances. Such approach introduces additional information which is over and above that is available when individual equations are treated separately (Moon et al., 2015). The SURE model is applicability to a large class of modelling and testing problems and also the relative ease of estimation hence improve upon OLS and provide the lowest standard error of the estimated parameters. The process uses the information about the correlation between the error terms to further improve the OLS estimates for improved coefficient estimates.

\section{Results and Discussions}

Table 1. Summary Statistics

\begin{tabular}{|c|c|c|c|c|c|c|c|}
\hline & Rgdp & TTR & DTR & ITR & OPN & POP & FDI \\
\hline \multicolumn{8}{|l|}{ Nigeria } \\
\hline Mean & 5.2029 & 12.2706 & -4.9400 & 10.6909 & 0.2413 & 8.1742 & -4.0400 \\
\hline Median & 5.1822 & 12.3050 & 11.9546 & 10.7016 & 0.2300 & 8.1735 & -4.4400 \\
\hline Maximum & 5.7180 & 12.7000 & 12.1100 & 11.0592 & 0.4000 & 8.2606 & -1.1400 \\
\hline Minimum & 4.5842 & 11.6400 & -7.9100 & 10.0934 & 0.1200 & 8.0895 & -8.0200 \\
\hline Std. Dev. & 0.4018 & 0.3717 & 1.9800 & 0.3065 & 0.0854 & 0.0545 & 2.2700 \\
\hline \multicolumn{8}{|l|}{ Ghana } \\
\hline Mean & 2.9911 & 9.5419 & 9.0738 & 9.0885 & 0.8838 & 7.3575 & -1.6500 \\
\hline Median & 3.0639 & 9.5650 & 8.9941 & 9.2302 & 0.9050 & 7.3583 & -1.8800 \\
\hline Maximum & 3.7043 & 10.3400 & 9.9168 & 9.5501 & 1.1600 & 7.4379 & -58930 \\
\hline Minimum & 2.1591 & 8.6300 & 8.3271 & 8.1490 & 0.6500 & 7.2747 & -3.3600 \\
\hline \begin{tabular}{|l|} 
Std. Dev. \\
\end{tabular} & 0.5026 & 0.5190 & 0.5159 & 0.4510 & 0.1553 & 0.0523 & 1.4100 \\
\hline \multicolumn{8}{|c|}{ Sierra Leone } \\
\hline Mean & 6.1094 & 11.7756 & 11.3071 & 11.1932 & 0.5606 & 6.7250 & -2.3200 \\
\hline \begin{tabular}{|l|} 
Median \\
\end{tabular} & 6.1043 & 11.7500 & 11.2280 & 11.0855 & 0.4700 & 6.7369 & -93655 \\
\hline Maximum & 6.5554 & 12.2900 & 11.9682 & 11.8862 & 0.9300 & 6.8098 & -86150 \\
\hline Minimum & 5.5154 & 11.1300 & 10.5992 & 10.2902 & 0.3600 & 6.6086 & -9.5000 \\
\hline Std. Dev. & 0.3174 & 0.3828 & 0.4666 & 0.5377 & 0.1958 & 0.0632 & 2.8100 \\
\hline \multicolumn{8}{|c|}{ Benin Republic } \\
\hline Mean & 5.5371 & 11.6431 & 10.9785 & 11.3348 & 0.5688 & 6.9435 & -1.3600 \\
\hline \begin{tabular}{|l|} 
Median \\
\end{tabular} & 5.5340 & 11.6750 & 10.9985 & 11.3765 & 0.5600 & 6.9464 & -39784 \\
\hline \begin{tabular}{|l|} 
Maximum \\
\end{tabular} & 5.6560 & 11.8400 & 11.1281 & 11.5439 & 0.7700 & 7.0366 & -32813 \\
\hline \begin{tabular}{|l|} 
Minimum \\
\end{tabular} & 5.4203 & 11.4100 & 10.8080 & 11.0710 & 0.4600 & 6.8419 & -4.3200 \\
\hline Std. Dev. & 0.0771 & 0.1440 & 0.1017 & 0.1588 & 0.0876 & 0.0621 & 1.4400 \\
\hline \multicolumn{8}{|c|}{ Burkina Faso } \\
\hline Mean & 5.3901 & 11.6644 & 11.0654 & 11.3962 & 0.4494 & 7.1610 & -1.3600 \\
\hline Median & 5.3806 & 11.6300 & 11.0034 & 11.3621 & 0.3700 & 7.1609 & -3.9780 \\
\hline \begin{tabular}{|l|} 
Maximum \\
\end{tabular} & 5.5429 & 12.0000 & 11.44279 & 11.7189 & 0.6700 & 7.2578 & -3.2813 \\
\hline \begin{tabular}{|l|} 
Minimum \\
\end{tabular} & 5.2081 & 11.2700 & 10.7038 & 10.9828 & 0.3100 & 7.0648 & -4.3200 \\
\hline Std. Dev. & 0.1170 & 0.2318 & 0.2554 & 0.2320 & 0.1388 & 0.0618 & 1.4400 \\
\hline
\end{tabular}

Source: Authors Computation 
Table 1 reveals that Nigeria had the highest growth of 5.72 and the lowest growth of 4.58 . The highest total tax revenue is 12.700 and 11.64 as the lowest. The table further reveals that the highest direct tax revenue 12.11 was collected in Nigeria while the lowest is -7.910; the highest indirect tax revenue is 11.05 and the lowest 10.09. Economic openness was mostly felt with a value of 0.4000 , while it was least felt with a value of 0.1200 . Highest population of 8.2606 was recorded while the lowest population of 8.0895 was recorded. The highest investment from foreigners stood at -1.1400 while the lowest stood at 8.0200. The basic statistics about Ghana shows that Ghana experienced the highest economic growth of 3.7043 and lowest economic growth of 2.1591. The highest total tax revenue was 10.3400 with lowest total tax revenue of 8.630. Meanwhile, the highest direct tax revenue of 9.916 was generated while the lowest is 8.3271, the highest indirect tax revenue was 9.5501 billion) and lowest stood at 8.1490. The highest population of 7.4379 was recorded with the lowest population of 7.2747 . The highest investment from foreigners (which stood at -589300 ) was experienced while the lowest stood at -3.3600 . All the variables are negatively skewed with mean values are less than unity. For Sierra Leone within the period covered by the study, the highest growth experienced was 6.5554 and the lowest was 5.5154. With regard to total tax revenue, the highest was 12.2900 and lowest tax revenue stood at 11.130. All the variables except economy openness are negatively skewed.

The table further reveals that the highest direct tax revenue of 11.1281 was collected in Benin Republic, while the lowest (N10.8080 billion) was collected, the highest indirect tax revenue of (N11.5439 billion), the lowest (N11.0710 billion) was collected respectively. Highest economic openness was 0.7700 with least value of 0.4600 . Similarly, Burkina Faso experienced the highest economic growth of 5.5429 and the lowest economic growth of 5.2081. The highest total tax revenue of 12.0000 , the lowest total tax revenue generated was N11.2700 billion. While economic openness was mostly felt value was 0.6700 , the least was 0.3100 . This also accounted for foreign direct investment in the country for the period with the mean value of -32812 .

\section{Panel Unit Root}

To avoid the apprehension of estimating spurious regression results, unit root test was conducted to check whether the panel series is stationary or not. Given the various conditions that characterize panel unit root tests, under the general assumption of cross-sectional independence, the Im-Persaran-Shin test was used. This test abhors the assumption of the Levin-Lin-Chu test, that $\rho_{i}$ must be the same for all series under the alternative hypothesis and the result presented in Table 2.

Table 2. Result of Panel Unit Root Test

\begin{tabular}{|c|c|c|c|c|c|c|c|c|c|}
\hline \multirow{3}{*}{ Series } & \multicolumn{4}{|c|}{ Levin, Lin and Chu test } & \multicolumn{4}{|c|}{ Impesaran and Shin test } & \multirow{3}{*}{$\begin{array}{l}\text { Order of } \\
\text { Integration }\end{array}$} \\
\hline & \multicolumn{2}{|c|}{ Levels } & \multicolumn{2}{|c|}{ First difference } & \multicolumn{2}{|c|}{ Levels } & \multicolumn{2}{|c|}{ First difference } & \\
\hline & t-stat & $\begin{array}{l}\text { Prob. } \\
\text { value }\end{array}$ & t-stat & $\begin{array}{l}\text { Prob. } \\
\text { value }\end{array}$ & t-stat & $\begin{array}{l}\text { Prob. } \\
\text { value }\end{array}$ & t-stat & $\begin{array}{l}\text { Prob. } \\
\text { value }\end{array}$ & \\
\hline InrGDP & -1.3374 & 0.0905 & -5.3884 & 0.0000 & 1.7714 & 0.9618 & -3.9970 & 0.0000 & I(1) \\
\hline InTTR & -2.3409 & 0.0096 & -4.5729 & 0.0000 & 0.6798 & 0.7517 & -3.9682 & 0.0000 & I(1) \\
\hline InDTR & 1.1704 & 0.8791 & -10.2138 & 0.0000 & 3.0473 & 0.9988 & -8.4453 & 0.0000 & I(1) \\
\hline InITR & -3.1323 & 0.0009 & -2.6542 & 0.0040 & -0.5418 & 0.2940 & -5.2872 & 0.0000 & I(1) \\
\hline $\operatorname{InOPN}$ & -0.8426 & 0.1997 & -6.2866 & 0.0000 & -0.1532 & 0.4391 & -5.5076 & 0.0000 & I(1) \\
\hline InFDI & -0.8157 & 0.2073 & -7.9745 & 0.0000 & 0.3220 & 0.6266 & -5.5408 & 0.0000 & I(1) \\
\hline $\ln \mathrm{POP}$ & -10.4549 & 0.0000 & & & -11.4282 & 0.0000 & & & I(0) \\
\hline
\end{tabular}

Source: Authors Computation

The output in table 2 shows that in both Levin-Lin-Chu test and the Im-Persaran-Shin tests, all the variables except population was found to be stationary at first difference, an indication that mixture of stationary and non-stationary series, the conduct of cointegration test is imperative. As in the pure time series framework, the variables in a regression function can be tested against cointegration by applying unit roots tests of the sort suggested in the previous sections to the residuals of the estimated regress. But since panel data is used in this study, the Pedroni cointegration statistics was employed. This framework deals 
with residual cross section dependence since it allows for a general error covariance matrix that covers all the variables in the panel. The first null hypothesis is rejected since the trace statistics (127.56) is greater than the $5 \%$ critical value (84.19). Following the same reasoning, we also reject the second null hypothesis, concluding that there is more one cointegrating vector among the variables.

Having established that our variables are cointegrated, further analysis was carried out with panel least squares method as the results are presented variously in Tables $4-6$. In all specification, economic growth is the dependent variable.

Table 4. Estimated result of the effect of tax revenue on economic growth

\begin{tabular}{|l|c|c|}
\hline \multicolumn{1}{|c|}{ Variable } & Fixed Effects & Random Effects \\
\hline InTTR & 0.4321 & 0.4143 \\
& $(0.0000)^{* *}$ & $(0.0000)^{* *}$ \\
\hline InOPN & -0.4544 & -0.3618 \\
& $(0.2020)$ & $(0.2428)$ \\
\hline InPOP & -2.1687 & -0.3697 \\
& $(0.3428)$ & $(0.1832)$ \\
\hline InFDI & 9.7000 & 1.1500 \\
& $(0.1861)$ & $(0.5776)$ \\
\hline \multicolumn{2}{|c|}{ Fixed Effects (Cross) } & Random Effects (Cross) \\
\hline Nigeria & 0.1665 & -0.4747 \\
\hline Ghana & -0.0117 & -0.0733 \\
\hline Sierra Leone & -0.4909 & 0.4634 \\
\hline Benin Republic & -0.4578 & 0.1075 \\
\hline Burkina Faso & -0.2061 & -0.0229 \\
\hline \multicolumn{2}{|c|}{} \\
\hline R overall & 0.6977 & 0.6968 \\
\hline SE of regression & 0.0645 & 0.0676 \\
\hline DW Static & 1.1959 & 1.1081 \\
\hline
\end{tabular}

Note: Figures in parentheses are the Prob. value, **Significant at 5 percent level

Source: Authors Computation

The result presented in Table 4 indicates there exists positive relationship between total tax revenue and economic growth. The estimated coefficient reveals that an increase in total tax revenue by $\$ 1$ cause economic growth to increase by $43.21 \%$ which is statistically significant at $5 \%$ level. This result corroborates the findings of Wisdom (2014), Ugwunta and Ugwuanyi (2015) and Onakoya et al. (2016) and contrasts Ferede and Dahlby (2012) who found a negative relationship between total tax revenue and economic growth. But for countries like Ghana, Sierra Leone, Benin and Burkina Faso, tax revenue has not accentuated growth even though these countries use taxation as key component of internally generated revenue to boost growth. The result also reveals that negative relationship exist between economic openness and economic growth. As evidence in the result, economic openness cause economic growth to decline by $45.44 \%$. This finding call for caution in opening the economy due to trade liberalization as such has not been too favourable to most ECOWAS countries. Given that most ECOWAS countries are monoproduct economy (for example Nigeria solely rely on oil, Ghana rely on crude petroleum, Sierra Leone rely on minerals such as diamond, Benin on cotton and Burkina Faso on gold as a means of foreign exchange) and the attendant consumption pattern of the populace that have high preference for foreign products. This result collaborates Musila and Yiheyis, (2015) and Polat et al., (2015). Contrary results were found by ZarraNezhad et al. (2014) and Nowbutsing (2014). In the same vein, increase in population had decreasing effect on growth by 2.16 percent, though not statistically significant at 5 percent. A rapidly growing population has serious implications on the provision of productive jobs. This result is in line with Popin (2017). Although the result portrays that there exist positive relationship between foreign direct 
investment and economic growth, the flow of foreign direct investment is relatively small, which accounts for its negligible contribution to growth (Lensink and Morrissey, 2006; Dasalegn 2014).

Table 5. Estimated result of the effect of direct tax revenue on economic growth

\begin{tabular}{|l|c|c|}
\hline \multicolumn{1}{|c|}{ Variable } & Fixed Effects & Random Effects \\
\hline InDTR & -3.08 & -2.73 \\
& $(-0.8814)$ & $(-0.7306)$ \\
\hline InOPN & -0.6102 & -3.0849 \\
& $(0.0001)^{* *}$ & $(0.0000)^{* *}$ \\
\hline InPOP & -8.1617 & -1.4793 \\
& $(0.0188)$ & $(0.0000)^{* *}$ \\
\hline InFDI & -4.7100 & -1.40 \\
& $(0.0158)$ & $(0.0162)$ \\
\hline & Fixed Effects (Cross) & Random Effects (Cross) \\
\hline Nigeria & 1.19241 & -1.1105 \\
\hline Ghana & -1.1906 & -2.2719 \\
\hline Sierra Leone & -3.3388 & 3.5153 \\
\hline Benin Republic & -2.1101 & 2.0099 \\
\hline Burkina Faso & -0.5529 & 0.8572 \\
\hline$R^{2}$ & 0.6905 & 0.5903 \\
\hline SE of regression & 0.1314 & 0.7434 \\
\hline DW Static & 0.3296 & 0.1996 \\
\hline
\end{tabular}

Note: Figures in parentheses are probability value ${ }^{*}$ Significant at 5 percent level

Source: Authors Computation

Table 6. Estimated result of the effect of indirect tax revenue on economic growth

\begin{tabular}{|l|c|c|}
\hline \multicolumn{1}{|c|}{ Variable } & Fixed Effects & Random Effects \\
\hline InITR & 0.4768 & 0.4713 \\
& $(0.0000)^{* *}$ & $(0.0000)^{* *}$ \\
\hline InOPN & -0.5661 & -1.1701 \\
& $(0.0000)^{* *}$ & $(0.0000)^{* *}$ \\
\hline InPOP & -6.7132 & -0.729215 \\
& $(0.0067)^{* *}$ & $(0.0000)^{* *}$ \\
\hline InFDI & -4.3800 & -1.1300 \\
& $(0.0020)^{* *}$ & $(0.0004)^{* *}$ \\
\hline & Fixed Effects (Cross) & Random Effects (Cross) \\
\hline Nigeria & 1.9399 & -1.6246 \\
\hline Ghana & -0.5261 & -1.1981 \\
\hline Sierra Leone & -2.7693 & 1.8110 \\
\hline Benin Republic & -1.9308 & 0.8066 \\
\hline Burkina Faso & -0.7137 & 0.2052 \\
\hline$R^{2}$ & 0.6951 & 0.6252 \\
\hline SE of regression & 0.0946 & 0.3176 \\
\hline DW Static & 1.0032 & 0.4516 \\
\hline
\end{tabular}

Note: Figures in parentheses are probability value, ${ }^{* *}$ Significant at 5 percent level

Source: Authors Computation

The estimated coefficient in Table 5 shows that a percentage increase direct tax decreased economic growth by 3.08 percent and such tax has not been productive in Ghana, Sierra Leone, Benin Republic and 
Burkina Faso. Even in Nigeria where positive effect was found, it is negligible. The policy implication that can deduce from this finding is that marginal impact of direct tax rate not only create disincentive to work and invest, it also has overall effect of lowering growth which is in tandem with the findings of Bleaney et al. (2001), Arnold, (2008), Ocran (2009) and Chigbu et al. (2012). Considering the effect of indirect tax revenue on economic growth presented in Table 6, the result depicts that a percentage increase in indirect tax boosts economic growth by about 47.7 percent, although such tax has not contributed significantly to growth. Since indirect tax is levied on consumption, the burden is shared among producers and consumers. This implies that an increase in such tax does not discourage consumption significantly, hence increased productive activities. All these would lead to increase in economic growth as asserted by N'Yilimon, (2015).

\section{Conclusions}

Even though taxation plays a great role in the growth process of an economy, not all categories of tax are productive. Using the SURE methodology, the study found that total tax revenue and indirect tax revenue foster economic growth while direct tax dampens growth, an indication that direct tax is unproductive in the countries under focus. These findings have some policy simulations. The government of the selected ECOWAS countries should implement measures that would broaden the tax (especially indirect tax) base rather and direct tax rate. This would eliminate tax evasion and improve revenue from both formal and informal sectors of the economy. The negative relationship between economic openness and economic growth implies that government needs to diversify and improve domestic production, export more commodities to improve revenue base instead of relying heavily on a single source. With foreign direct investment encouraged, caution should not be thrown to the wind and such investment should be directed to specific sectors of the economy where they are needed most because it possible for foreign direct investment to be contributing to growth without necessarily improving welfare in the host country. For those countries where indirect tax are unproductive, there is need to broaden indirect tax base instead of direct tax rate.

\section{References}

1. Adeyeye, G.B. (2004). An overview of personal income tax in Nigeria: A case study of Lagos state, Global Journal of Accounting, 1(2), 15-33.

2. African Development Indicators (2015). Retrieved from Https://Data.Worldbank.Org/DataCatalog/Africa-Development-Indicators on the 5th of February 2017.

3. Ahmed, Q. M. (2010). Determinants of tax buoyancy: empirical evidence from developing countries, European Journal of Social Sciences, 13(3), 408-414.

4. Angelopoulos, K., Malley, J., \& Philippopoulos, A. (2012). Tax structure, growth, and welfare in the United Kingdom, Oxford Economic Papers, 64(2), 237-258.

5. Anyaduba, J.O. (2004). Partnership taxation in Nigeria, ICAN Student Journal, 9(2), 15-17.

6. Arisoy, I., \& Unlukaplan, I. (2010). Tax composition and growth in turkey: an empirical analysis, Ibadan Research Journal of Finance \& Economics, 59(1), 50-61.

7. Arnold, J. (2008). Do tax structures affect aggregate economic growth; empirical evidence from a panel of OECD countries, OECD Economics Department Working Papers, 5(2), 44-49. Retrieved from Http://Dx.Doi.Org/10.1787/236001777843.

8. Atkinson, A.B. (1977). Optimal taxation and the direct versus indirect tax controversy, Canadian Journal of Economics, 3(10), 590-606.

9. Bania, N., Gray J.A., \& Stone J.A. (2007). Growth, taxes, and government expenditures: growth hills for United States, National Tax Journal, 60(2) 193-204.

10.Barro, R. (1990). Government spending in a simple model of endogenous growth, Journal of Political Economy, 1(2) 33-40.

11.Bleaney, M., Gemmell, N., \& Kneller, R. (2001). Testing the endogenous growth model: publicexpenditure, taxation, and growth over the long-run, Canadian Economics,4(1,) 36-57. 
12.Brian, G., Alex, L., \& Stephen, L. (2011).A matched pair analysis of state growth differences, Contemporary Economic Policy. Retrieved from Https://Economic growth, a matched pair analysis/DataCatalog/ on the 7th of July 2017.

13.Brautigam, D. (2008). Taxation and governance in Africa, Journal of Economics, 2(1) 22-27. Retrieved from Http://www.Aei.Org/Publication/Taxation-And-Governance-In-Africa

14.Chaudhry, S., \& Munir, F. (2010). Determinants of low tax revenue in Pakistan, Pakistan Journal of Social Sciences, 30(2), 439-452.

15.Chigbu E, Akujuobi E, Appah, E. (2012). An empirical study on the causality between economic growth and taxation in Nigeria, Curriculum Resource Journal of Economic Theory 4(2), 29-38.

16.Dackehag, M., \& Hansson, A. (2012). Taxation of income and economic growth: an empiricalanalysis of 25 rich OECD countries, Journal of Economic Development, 21(1), 93-118.

17.Dasalegn, M., J. (2014). Value added tax as a tool for national development in Ethiopia, Resource Journal of finance, 15 (5), 20-28.

18.Deloitte, (2017).Guide to fiscal information key economies in Africa. Retrieved January $4^{\text {th }} 2017$ from www2.deloitte.com/za/en/pages/tax/a.

19.Dike, M.A.C. (2014). An overview of the Nigerian tax system: implications for foreign Investors, at the Nigerians in Despora organisation, UK south investment conference.

20.Dritsakil, C. \&Gialitaki, K. (2005). Taxes and economic indicators: an empirical investigation for Greece, Spoudai, 55(3).

21.ECOWAS (2016). Basic information of ECOWAS. Retrieved on December $5^{\text {th }} 2016$, Fromhttp://www.ecowas.int/about-ecowas/basic-information.

22.Easterly, W \& Rebelo, S. (1993). Fiscal policy and economic growth; an empirical investigation, Journal of Monetary Economics, 32(1), 417-458.

23.Engen, E. M., \& Skinner, J. (1992).Fiscal policy and economic growth, National Bureau of Economic Research, No. W4223.

24.Engen, E., \& Skinner, J. (1996).Taxation and economic growth, National Tax Journal, 49 (1), 617642.

25.Fadare, S. (2010). Recent Banking sector reforms and economic growth in Nigeria, Middle Eastern Finance \& Economics, 1(8), 77-88.

26.Ferede, E., \& Dahlby, B. (2012). The impact of tax cuts on economic growth: evidence from the Canadian provinces, National Tax Journal, 65(3) 563-594.

27.FIRS (2017). Data on total tax revenue in Nigeria. Retrieved from http://www.firs.gov.ng/taxrevenue-statistics.on the $22^{\text {nd }}$ of March.

28.Greenidge, K., \& Drakes, L. (2009).Tax policy and macroeconomic activity in Barbados. Retrieved from Http://Www.Centralbank.Org.Bb on the $2^{\text {nd }}$ of August 2017.

29.Gwartney, J. D., \& Lawson, R. A. (2006). The impact of tax policy on economic growth income distribution and allocation of taxes, Social Philosophy \& Policy, 1(23), 28-52.

30.Heij, C., De Boer, P., Franses, P.H., Kloek, T \& Van Dijk, H. K. (2004).Econometric methods with applications in business and economics, New York: Oxford University Press Inc. $163-180$

31.Hodge, D. (2006). Inflation and growth in South Africa, Cambridge Journal of economics, 30(1)

32. Holcombe, R., \& Lacombe, D. (2004). The effect of state income taxation on per capita income growth, Public Finance Review, 32(3), 292-312.

33.IMF, (2005).World Economic Outlook, international monetary fund, Washington DC.

34.Iyke, B.N., \&Takumah, W. (2015). The links between economic growth and tax revenue in Ghana: an empirical investigation. University of South Africa, University of Cape Coast. Retrieved on the $22^{\text {nd }}$ of August 2016 from Https://Mpra.Ub.Uni-uenchen.De/67281/Mpra Paper No. 67281.

35.Jones, B. (2001). Convergence criteria and monetary integration in ECOWAS, UN-ECA, SubRegional Development Centre, West Africa, Development Bulletin, 4(8), 33.

36.Jones, S., \& Rhoades S. (2011).Principles of taxation for business and investment planning, New York: McGraw-Hill Companies. 
37.Kaplow, L. (2010). The theory of taxation and public economics, New Jersey: Princeton University. Press.

38.Karras A., \& Furceri, D. (2009).Taxes and growth in Europe south, Eastern Europe journal of Economics, 2(2) 181- 204.

39.King, R., \& Rebelo, S. (1990). Public Policy and economic growth: developing neoclassical implications, Journal of Political Economy, 98 (5), 126-150.

40.Koester, R., \& Kormendi, R. (1989). Taxation, aggregate activity and economic growth: crosscountry evidence on some supply-side hypothesis, Economic Inquiry, 4(27), 367-386.

41.Lee, Y., \& Gordon R. (2004).Tax structure and economic growth, Journal of Public Economics, 89(5) 1027-1043.

42.Lensink, R. \& Morrissey, O. (2001).Foreign direct investment: flows, volatility, and the impact on growth, Oxford U.K: Blackwell Publishing Limited.

43.MFG (2017). Retrieved from http://www.mofep.gov.gh/?q=content/gra-targets-x-revenue2015.on the $2^{\text {nd }}$ of May 2017.

44.Macek, R. (2014). The impact of taxation on economic growth: case study of OECD Countries, Review of Economic Perspectives, 1(14), 309-328.

45. Maisto, G. (1988). Tax treatment of cost contribution arrangements, Boston: Kluwer Lawand Taxation Publishers.

46.Moon, H., R. Perron, B. \& Phillips C., B. (2015). Incidental parameters and dynamic panel Modelling,cowles foundation for research in economics Yale university, 4(1).

47.Mura, P.O. (2015) Tax composition and economic growth: A panel-model approach for Eastern Europe, Annals of the constant in Brâncuşi, 1(1) 20-25.

48.Musila, J. W., \&Yiheyis, Z. (2015). The impact of trade openness on growth: the case of Kenya, Journal of policy modelling, 37(1) 342-354.

49.Myles, G. D. (2009). Taxation and economic growth, Fiscal Studies, 1(21), 141-168.

50.Ndiaye, M., B., O., \&Korsu R., D. (2011). Tax effort in ECOWAS countries, West African Monetary Agency, Mimeo 3(1).

51.Nowbutsing, B. M. (2014). The impact of openness on economic growth: case of Indian Ocean Rim countries, Journal of Economics \& Development Studies, 2(1) 407-427.

52.N'Yilimon. N. (2015) Taxes and economic growth in developing countries: a dynamic panel approach, Munich personal Repec archive, Retrieved from https://mpra.ub.uni-muenchen.de/61346/ on the $23^{\text {rd }}$ of December 2017.

53.Nzotta, S.M. (2007). Tax evasion problems in Nigeria, Critique Journal of Nigeria Account, 12(1), 40-43.

54.Obara, C. L and Nangih (2017). Tax compliance barriers and internally generated revenue in Nigeria: Empirical from small and medium enterprises in Port-Harcourt metropolis, International Journal of Academic Research in Accounting, Finance \& Management Sciences 7(4), 169-176, doi:10.6007/IJARAFMS/v7-i4/3481.

55.Obwona, M., \& Muwonge, A. (2002). The efficiency and effectiveness of the revenue administration in Uganda, Copenhagen: Danish Institute Series.

56.Ocran K. M. (2009). Fiscal policy and economic growth in South Africa, .A paper presented at the centre for the study of African economies conference on economic development in Africa, St. Catherine's College, Oxford University, UK. March 22-24.

57.OECD (1991). Rising tax revenues are key to economic development in African countries. Retrieved July $2^{\text {nd }} 2016$ from http://www.oecd.org/tax/rising-tax-revenues-are-key-to-economicdevelopment-in-african-countries.htm.

58.OECD.STAT (2017). Retrieved from https://stats.OECD.org/Index.aspx?DataSetCode=REIV on the $21^{\text {st }}$ of January 2017.

59.Ojo, S. (2003).Fundamental principle of Nigeria taxation, Lagos, Sagribra Tax Publication.

60.Okafor, R. G. (2012). Tax revenue generation and Nigerian economic development, European Journal of business \& management, 4(19)49-57. 
61.Onakoya, A.B., Afintinni, O.I., \& Ogundayo, G.O. (2016).Taxation revenue and economic growth in Africa, Journal of Accounting and Taxation,9(2) 11-22.

62.Padovano, F., \& Galli, E. (2001).Tax rate and economic growth in the OECD countries, Economic Inquiry, 1(39), 44-57.

63.Peden, E.A. (1991). Productivity in the United States and its relation with government activity: analysis of 57 years, Journal of Accounting \& Taxation, 1(3) 23-28.

64.Pfister, M. (2009). Taxation for investment and development: an overview of policy challenges in Africa, ministerial meeting and expert roundtable of the NEPAD Africa investment initiative on November 11-12.

65.Plosser, C.I. (1992). The search for growth, Federal Reserve of Kansas City symposium series, policies for long-run economic growth, Economic Researcher, 35(1) 57-86.

66.Polat, A., Shahbaz, M., Rehman, I. U., \& Satti, S. L. (2015). Revisiting linkages between financial development, trade openness and economic growth in South Africa: Fresh evidence from combined cointegration test, Quality \& Quantity, 49 (1) 785-803.

67.Popin (2017).Population and development in Africa, OAU \& ECA, Retrieved From Http://Www.Undp.Org/Popin on the $3^{\text {rd }}$ Of September 2017.

68.Poulson, B. W., \& Kaplan, J. G. (2008).State income taxes and economic growth, Cato Journal, 28(1) 53-71.

69.Prammer, D. (2011). Quality of taxation and the crisis: tax shifts from a growth perspective, taxation, Working Paper 29.

70.Romer, P.M. (1986) Increasing returns and long run growth, Journal of Political Economy, 94(5) 1002-1037.

71.Romer, P. M. (1994).The origins of endogenous growth, Journal of Economic Perspectives, 8 (1) 3-

22.

72.Saleemi, N. A. (2005). Taxation simplified, 5th Ed. Nairobi, Saleemi Publications Limited.

73.Santiago, A.O., \& Jiae, Y. (2012). Tax composition and growth: A broad cross-country perspective, International Monetary Fund Working Paper /12/257, fiscal affairs department., Retrieved October $27^{\text {th }}$ 2016from https://www.imf.org/external/pubs/ft/wp/2012/w12257.pdf.

74.Scarlett H., G. (2011), Tax policy and economic growth in Jamaica, Bank of Jamaica working paper.

75.Slemond, J. (2003). The truth about taxes and economic growth, challenge, 46(1) 5-14.

76.Steven, F.K., Niel, J.S., \& Jurie V. (2005).Economic growth and the structure of Taxes in South Africa, South African journal of Economics, 73(2).Retrieved April $3^{\text {rd }} 2016$ from http://onlinelibrary. wiley.com/ doi/ 10.1111/j.1813-6982.2005.00013.x/full.

77.Srivastava, V., K. Giles and David, E.A. (1987). Seemingly unrelated regression equations models: estimation and inference, New York, Marcel Dekker.

78.Tomljanovich, M. (2004).The role of state fiscal policy in state economic growth, Contemporary Economic Policy, 22(3), 318-320.

79.Tosun, M., \& Abizadeh, S. (2005). Economic growth and tax components: an analysis of tax change in OECD, Application of Economics, 37(1), 2251-2263.

80.Ugwunta, O.D \&Ugwuanyi, U.B. (2015).Effect of distortionary and non-distortionary taxes on economic growth: Evidence from Sub-Saharan African countries, Journal of Accounting \& Taxation, 7(6), 106-112.

81.United .Nations (2003). Foreign direct investment policies for development, National and International perspectives, New York and Geneva.

82.UN Millennium Project (2005).Investing in development, New York: United Nations.

83.WAMI (2015). Retrieved from.Www.Wami-Imao.Org/ on the 5th of February 2017.

84.World Development Indicators (2016). The World Bank, World Development Indicators, Retrieved March $3^{\text {rd }} 2016$ from http://databank.worldbank.org/data/home.aspx.

85.Wisdom, T. (2014). Tax revenue and economic growth in Ghana: A cointegration approach. MPRA,

5.

86.Wiza M. (2014). The relationship between economic growth and inflation in the South African economy, Mediterranean Journal of Social Sciences, 5(15). 
87.Worlu, C. N., \& Nkoro, E. (2012). Tax revenue and economic development in Nigeria: A macroeconometric approach, Academic Journal of Interdisciplinary Studies, 48(1), 198-211.

88.Xing, J. (2011). Does tax structure affect economic growth, empirical evidence from OECD countries, Oxford University for business taxation working paper, 11/20.

89.Xing, J. (2012). Tax structure and growth: how robust is the empirical evidence, Economic Letters, 11(7), 379-382.

90.Yakovlev, P. A. (2014). State economic prosperity and taxation, Mercatus center George manson university working paper 1(2), 14-19.

91.Yi, F., \& Suyono, E. (2014).The relationship between tax revenue and economic growth of Hebei province based on the tax multiplier effect, Global Economy and Finance Journal, 7(2): 1-18.

92.Zarra-Nezhad, M., Hosseinpour, F., \& Arman, S. A. (2014). Trade-growth nexus in developing and developed countries: An application of extreme bounds analysis, Asian Economic \& Financial Review, 4 (1) 915-929.

93.Zellner, A. (1962). An efficient method of estimating seemingly unrelated regressions and tests for aggregation bias, Journal of the American Statistical Association, 57 (1) 348-368, doi: 10.2307/2281644.

94.Zipfel, F., \& Heinrichs, C. (2012).The impact of tax systems on economic growth in Europe, Deutsche Bank Research, Retrieved January $1^{\text {st }} 2017$ from https://mpra.ub.uni-muenchen.de/59781/ 1/MPRA_paper_. 